\title{
PENGARUH BRISK WALKING (Jalan cepat) TERHADAP PENURUNAN BERAT BADAN SISWI SMP NEGERI 2 KOTA BENGKULU
}

\author{
Mangalap Sangap Sitorus \\ Program Studi Pendidikan Jasmani FKIP Universitas Bengkulu \\ Email : sangapsitorus1995@gmail.com \\ Dian Pujianto \\ Universitas Bengkulu \\ Bogy Restu Ilahi \\ Universitas Bengkulu
}

\begin{abstract}
ABSTRACK
Penelitian ini bertujuan untuk mengetahui pengaruh Brisk Walking( jalan cpat) terhadap penurunan berat badan siswi SMP Negeri 2 Kota Bengkulu. Apakah terdapat Pengaruh Brisk Walking (jalan cepat) terhadap penurunan berat badan siswi SMP Negeri 2 Kota Bengkulu.Jenis penelitian yang digunakan dalam penelitian ini adalah penelitian kuantitatif Experimen One Group Pretest-PostestDesign. Populasi dalam penelitian ini adalah siswi SMP Negeri 2 Kota Bengkulu Kelas VII dan VIII yang mengalami obesitas yang berjumlah 25 orang. Hasil penelitian Pengaruh Brisk Walking (jalan cepat) SMP Negeri 2 Kota Bengkulu diperoleh hasil pretest sebesar 70,27 kg dan hasil rata-rata posttest sebesar 68,66 kg dengan selisih 1,61kg dan hasil t hitung sebesar 7,19 > dari t table 1,696. Berdasarkan uji statistik dengan $\alpha=5 \%(0,05)$ bahwa Ho ditolak atau menerima Ha dapat ditarik simpulan bahwa Briks Walking (jalan cepat) berpengaruh secara signifikan terhadap penurunan berat badan.
\end{abstract}

Kata Kunci : Brisk Walking (jalan cepat), Penurunan Berat Badan

\begin{abstract}
Abstrack
This Study Aims To Determine The Effect Of Brisk Walking On Weight Loss For Female Junior High School Students 2 In The City Of Bengkulu. Is There A Brisk Walking Effect On The Weight Loss Of Public Junior High School Students 2 In The City Of Bengkulu. The Type Of Research Used In This Study Was Quantitative Research Experimental One Group Pretest-Posttest Design.The Population In This Study Were State Junior High School Students 2 In Bengkulu City In Grades 7 And 8 Who Were Obese, Amounting To 25 People. The Results Of The Study Of The Influence Of Brisk Walking Public Junior High School 2 City Of Bengkulu Obtained Pretest Results Of $70.27 \mathrm{Kg}$ And Posttest Average Results Of $68.66 \mathrm{Kg}$ With A Difference Of $1.61 \mathrm{Kg}$ And T Count Results Of 7.20> From T Table 1.696. Based On Statistical Tests With $\alpha=5 \%$ (0.05) That Ho Is Rejected Or Accepts Ha Can Be Drawn Conclusions That Brisk Walking Has A Significant Effect On Weight Loss Of Female Junior High School Students 2 In The City Of Bengkulu.
\end{abstract}

Keywords: Brisk Walking, Weight Loss 


\section{PENDAHULUAN}

Olahraga merupakan suatu bentuk dari pendidikan yang tidak lepas dari pendidikan secara keseluruhan. Sebagian dari pendidikan, tujuan olahraga harus sesuai dengan tujuan pendidikan nasional secara keseluruhan yaitu mencerdaskan kehidupan bangsa dan pengembangan manusia Indonesia seutuhnya yaitu manusia yang beriman dan bertakwa terhadap Tuhan Yang Maha Esa dan berbudi pekerti yang luhur memiliki kemampuan dan keterampilan, kesehatan jasmani dan rohani, berkepribadian yang mantap dan mandiri serta bertanggung jawab. Overweight merupakan suatu peningkatan berat badan sebanyak $10 \%$ sampai $20 \%$ dari batas berat badan normal, sedangkan obesitas dapat terjadi apabila adanya peningkatan berat badan lebih dari $20 \%$ dari batas Normal berat badan dan terjadi penumpukan lemak yang lebih dari batas Normal pada jaringan adiposa dan dapat merusak kesehatan (Cristine, 2016:5).Sekitar 4 juta orang meninggal karena penyakit kardiovaskuler, diabetes, kanker, dan penyakit lainnya yang terkait kelebihan berat badan, meningkat $28 \%$ dibandingkan tahun 1990 menurut hasil riset. Sedangkan penderita obesitas di Indonesia cukup tinggi, penelitian terakhir menyebutkan bahwa penderita laki-laki berjumlah 9,16\% dan penderita wanita sekitar 11,02\%. Angka ini akan terus meningkat jika kesadaran masyarakat untuk menjaga pola makanan dan menurunkan berat badan masih kecil (Yahya 2017:12)

\section{METODE}

Metode penelitian adalah keseluruhan rencana untuk mendapatkan jawaban atas pertanyaan yang sedang dipelajari dan untuk menangani berbagai tantangan terhadap bukti penelitian yang layak.Dalam merancang penelitian ini, peneliti memutuskan mana yang spesifik yang akan diadopsi dan apa yang akan mereka lakukan untuk meminimalkan bias dan meningkatkan interpretabilitas hasil (Creswell, 2009:85).

Berdasarkan permasalahan yang diteliti maka penelitian ini menggunakan rancangan pra-pasca tes dengan penelitian pre eksperimen (pre-post test design).Pada desain ini pre test ada pre test pada saat subjek sebelum diberikan perlakuan, setelah itu perlakuan subjek diberikan post test sebelum diberi perlakuan. Dengan demikian hasil perlakuan dapat diketahui lebih akurat, karena dapat membandingkan dengan keadaan sebelum diberi perlakuan (Pujianto dan Insanistyo, 2017;35).

\section{HASIL DAN PEMBAHASAN}

Adapun hasil tes Brisk Walking( Jalan Cepat ) sebelum dan sesudah diberikan perlakuan sebagai berikut:

Tabel 4.1 Berat badan awal dengan IMT.

\begin{tabular}{l|l|l|c|c|c}
$\mathrm{N}$ & $\begin{array}{l}\text { Be } \\
\mathrm{0}\end{array}$ & $\begin{array}{l}\text { Ktu } \\
\mathrm{k}\end{array}$ & $\mathrm{IMT}$ & $\begin{array}{c}\text { Juml } \\
\text { ah }\end{array}$ & $\begin{array}{c}\text { Persen } \\
\text { tase } \\
(\%)\end{array}$ \\
\hline 1 & $\begin{array}{l}\text { Kur } \\
\text { us }\end{array}$ & $\begin{array}{l}\text { Kekurangan } \\
\text { berat badan } \\
\text { tingkat } \\
\text { rendah }\end{array}$ & $\begin{array}{l}<17, \\
0\end{array}$ & 0 & 0 \\
\hline & $\begin{array}{l}\text { Kekurangan } \\
\text { berat badan } \\
\text { tingkat } \\
\text { rendah }\end{array}$ & $\begin{array}{c}17,0 \\
-\end{array}$ & 0 & 0 \\
\hline 2 & $\begin{array}{l}\text { Nor } \\
\text { mal }\end{array}$ & $\begin{array}{c}>18,5 \\
5\end{array}$ & 0 & 0 \\
\hline 3 & $\begin{array}{l}\text { Ge } \\
\text { mu }\end{array}$ & $\begin{array}{l}\text { Kelebihan } \\
\text { berat badan } \\
\text { tingkat } \\
\text { ringan }\end{array}$ & $\begin{array}{c}>25, \\
0-\end{array}$ & 8 & 32 \\
\hline & & $\begin{array}{l}\text { Kelebihan } \\
\text { berat badan }\end{array}$ & $\begin{array}{c}>27, \\
0\end{array}$ & 17 & 68
\end{tabular}




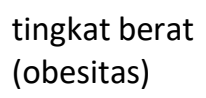

Menurut tabel pretest di atas, jumlah siswi yang mengalami kategori berat badan tingkat ringan berjumlah 8 siswi atau $32 \%$, sedangkan siswi yang mengalami kategori berat badan tingkat berat (obesitas) berjumlah 17 siswi atau 68\%.

Analisis data digunakan untuk menjawab hipotesis yang diajukan yaitu adanya pengaruh Brisk Walking terhadap penurunan berat badan pada siswi SMP Negeri 2 Kota Bengkulu.

Gambar 4.1

Grafik Berat Badan awal (Pretest)

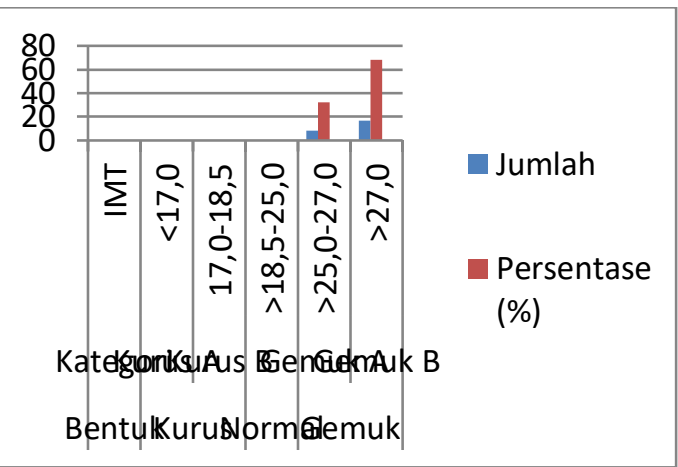

Gambar grafik 4.1 di atas menunjukkan bahwa hasil pretest dari 25 sampel yang sudah dihitung IMT nya, sampel yang termasuk dalam kategori kelebihan berat badan tingkat ringan berjumlah 8 orang atau 32\% dan yang termasuk dalam kategori kelebihan berat badan tingkat berat berjumlah 17 orang atau $68 \%$.

Tabel 4.2 Berat badan akhir

\begin{tabular}{|c|c|c|c|c|c|}
\hline $\mathrm{N}$ & $\begin{array}{l}\text { Bentu } \\
\mathrm{k}\end{array}$ & Kategori & IMT & $\begin{array}{c}\text { Jumla } \\
\mathrm{h}\end{array}$ & $\begin{array}{c}\text { Persen } \\
\text { tase } \\
(\%) \\
\end{array}$ \\
\hline 1 & Kurus & $\begin{array}{l}\text { Kekurang } \\
\text { an berat } \\
\text { badan }\end{array}$ & $\begin{array}{c}<17 \\
0\end{array}$ & 0 & 0 \\
\hline
\end{tabular}

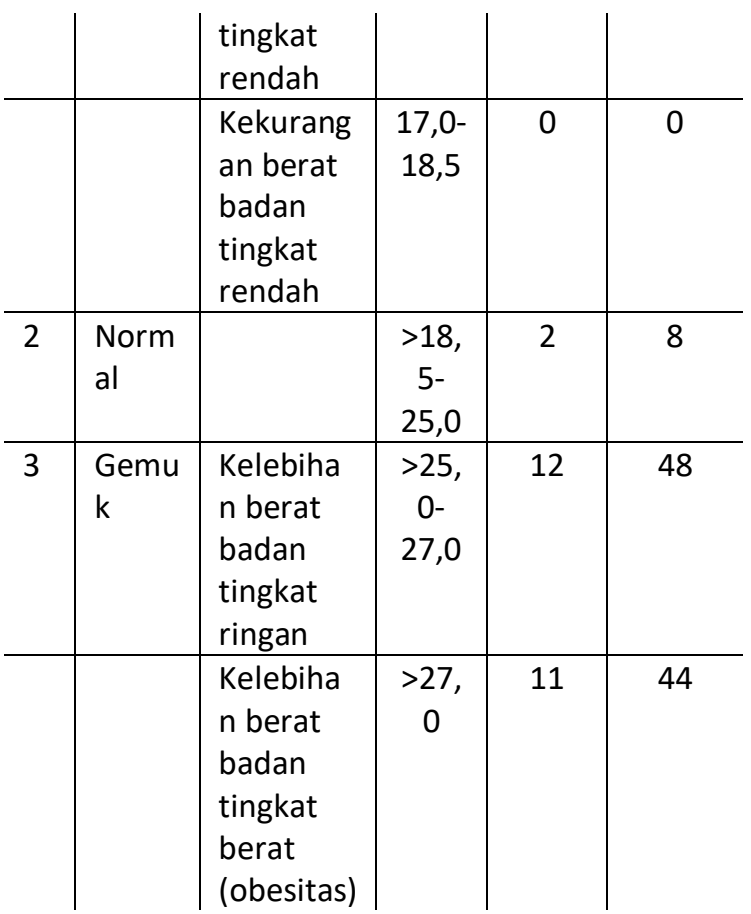

Dari tabel di atas, jumlah siswi yang termasuk dalam kategori normal berjumlah 2 orang atau 8\%, sedangkan siswi yang termasuk ke dalam kategori kelebihan berat badantingkat ringan berjumlah 12 orang atau $48 \%$, dan jumlah siswi yang termasuk ke dalam kategori berat badan berlebih (obesitas) berjumlah 11 orang atau 44\%.

Gambar 4.2

Grafik Diagram Berat Badan Akhir (Postest)

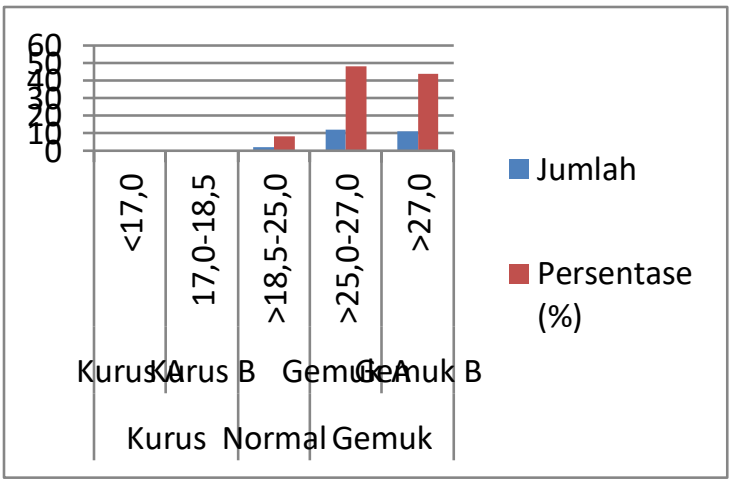

Grafik diagram 4.2 dapat diketahui dari 25 sampel yang sudah diberi perlakuan jumlah siswi yang masuk dalam kategori normal berjumlah 2 orang atau $8 \%$, 
sedangkan siswi yang termasuk dalam kategori kelebihan berat badan tingkat ringan berjumlah 12 orang atau 48\%, dan siswi yang masuk dalam kategori berat badan tingkat berat berjumlah 11 orang atau 44\%. Aktivitas jasmani secara nyata telah memberikan pengaruh positif terhadap perkembangan anak (Dian Pujianto 2019:84)

\section{PENUTUP}

\section{Simpulan}

Berdasarkan hasil penelitian dapat disimpulkan bahwa Pengaruh Brisk Walking (Jalan cepat) terhadap penurunan berat badan siswi SMP Negeri 2 Kota Bengkulu. Oenurunan berat badan terlihat pada perbandingan perubahan rata-rata Pretest dan Posttest. Dari data yang sudah diperoleh, hasil Pretest sebesar 70,27dan hasil rata-rata Posttest sebesar 68,66dengan selisih 1,61. Hasil penelitian menunjukkan bahwa selisih Mean antara Pretest danPosttest siswi setelah diberikan perlakuan jalan cepat sebanyak 16 kali pertemuan dapat menunjukkan penurunan berat badan terhadap siswi SMP Negeri 2 Kota Bengkulu.

Dan dari hasil t hitung sebesar 7,20> dari t tabel 1,696. Bahwa ada pengaruhBrisk Walking (jalan cepat) terhadap penurunan berat badan siswi SMP Negeri 2 Kota Bengkulu yang Signifikan.Dengan demikian hipotesis ( $\mathrm{Ha}$ ) yang berbunyi "Ada pengaruh Brisk Walking (jalan cepat) terhadap penurunan berat badan siswi SMP Negeri 2 Kota Bengkulu", diterima.

\section{Saran-saran}

a.Bagi guru atau sekolah untuk memberikan edukasi terhadap akan bahaya penyakit tidak menular seperti berat badan berlebih (obesitas). b. Sebaiknya siswi senantiasa dalam menurunkan berat badan jangan hanya dilakukan dalam jangka pendek, tetapi harus berkelanjutan atau jangka panjang karena berat badan akan bertambah kapan saja ketika pola hidup kita kembali kepada pola hidup yang buruk.

c. Bagi peneliti yang ingin melanjutkan penelitian ini agar dapat menjadikan penelitian ini sebagai bahan informasi dan penelitian dengan populasi atau sampel yang berbeda dan dalam jumlah yang lebih banyak lagi.

penelitian dengan populasi dan sampel yang berbeda dengan jumlah yang lebih banyak lagi.

\section{DAFTAR PUSTAKA}

Adhi, Ansor. 2016. Tetap Sehat Dan Bugar Di Usia 40 Tahun. Yogyakarta: Healthy.

Arisman, 2014.Buku Ajara Ilmu Gizi Obesitas,Diabetes Mellitus, \& Dislipidema. Jakarta: Sagung Seto

Bickley, Lynn S. 2014. Bates Buku Saku Pemeriksaan Fisik \& Riwayat Kesehatan Edisi 7. Jakarta: 2014

Creswell, John. 2009. Research Design Qualitative, Quantitative And Mixed.Methods Approaches Third Edition. American : Sage

Frans Dkk. 2016.Pengaruh Brisk WalkingExercise

Terhadap Penurunan Kadar Glukosa Pada Lansia Potensi Diabetes 
Militus $\quad$ Di Posyandu
Rampal.

Hendra,Cristine. 2016. Faktor-

Faktor Terhadap Obesitas

Pada Remaja Di Kota

Bitung.

Katsilambros Nichoulas. 2014 A

Randomized, Controlled

Trial On The Effect Of No-

Surgical Periodental

Therapi In Patients Whit

Type 2 Diabetes.

Kusmana, Dede. 2013. Pengaruh

Olahraga Jalan Cepat

Dan Diet

TerhadapTekanan Darah

Penderita Prahipertensi

Pria.

Pujianto Dian. 2019. Aktifitas

Jasmani Dan Persepsi

Gerak Anak Usia Dini 